\title{
Myostatin is expressed in bovine ovarian follicles and modulates granulosal and thecal steroidogenesis
}

\author{
Warakorn Cheewasopit ${ }^{1 \dagger}$, Mhairi Laird ${ }^{1}$, Claire Glister ${ }^{1}$ and Phil G Knight ${ }^{1}$ \\ ${ }^{1}$ School of Biological Sciences, Hopkins Building, University of Reading, Whiteknights, Reading, UK and \\ Correspondence should be addressed to P G Knight; Email: p.g.knight@reading.ac.uk
}

${ }^{\dagger}$ (W Cheewasopit is now at Department of Biology, Ramkhamhaeng University, Bangkapi, Bangkok, Thailand)

\begin{abstract}
Myostatin plays a negative role in skeletal muscle growth regulation but its potential role in the ovary has received little attention. Here, we first examined relative expression of myostatin (MSTN), myostatin receptors (ACVR1B, ACVR2B and TGFBR1) and binding protein, follistatin (FST), in granulosa (GC) and theca (TC) cells of developing bovine follicles. Secondly, using primary GC and TC cultures, we investigated whether myostatin affects steroidogenesis and cell number. Thirdly, effects of gonadotropins and other intrafollicular factors on MSTN expression in GC and TC were examined. MSTN, ACVR1B, TGFBR1, ACVR2B and FST mRNA was detected in both GC and TC at all follicle stages. Immunohistochemistry confirmed follicular expression of myostatin protein. Interestingly, MSTN mRNA expression was lowest in GC of large oestrogen-active follicles whilst GC FST expression was maximal at this stage. In GC, myostatin increased basal CYP19A1 expression and oestradiol secretion whilst decreasing basal and FSH-induced HSD3B1 expression and progesterone secretion and increasing cell number. Myostatin also reduced IGF-induced progesterone secretion. FSH and dihydrotestosterone had no effect on granulosal MSTN expression whilst insulin-like growth factor and tumour necrosis factor-alpha suppressed MSTN level. In TC, myostatin suppressed basal and LH-stimulated androgen secretion in a follistatin-reversible manner and increased cell number, without affecting progesterone secretion. LH reduced thecal MSTN expression whilst BMP6 had no effect. Collectively, results indicate that, in addition to being potentially responsive to muscle-derived myostatin from the circulation, myostatin may have an intraovarian autocrine/paracrine role to modulate thecal and granulosal steroidogenesis and cell proliferation/survival.

Reproduction (2018) $\mathbf{1 5 6} 375-386$
\end{abstract}

\section{Introduction}

Ovarian follicle development is dependent on the actions and interactions of systemic and intraovarian regulatory signals. Whilst pituitary gonadotrophins $(\mathrm{FSH}, \mathrm{LH})$ are the key endocrine signals driving follicle development, a complex array of locally produced growth factors also contribute to the modulation of follicular somatic cell proliferation and differentiation, 'initial' and 'cyclic' follicle recruitment, steroidogenesis, dominant follicle selection and ovulation (Campbell et al. 2003, Webb et al. 2003). Prominent amongst these are various members of the transforming growth factor $-\beta$ (TGF- $\beta$ ) superfamily including growth and differentiation factor-9 (GDF9), anti-Mullerian hormone, inhibins, activins and several bone morphogenetic proteins (BMP) including BMP2, BMP4, BMP6 and BMP7 (Shimasaki et al. 2004, Knight \& Glister 2006). In the present study, we examined the potential involvement of another TGF- $\beta$ superfamily member, myostatin (also known as GDF8) in regulating ovarian follicle function.

Myostatin is well recognised for its negative autocrine/ paracrine role in skeletal muscle development (Otto
\& Patel 2010, Schiaffino et al. 2013). Myostatin-null mice show a pronounced increase in muscle mass due to muscle fibre hyperplasia and hypertrophy (McPherron et al. 1997). Naturally occurring inactivating mutations in the myostatin gene are also evident in several species including bovine (Kambadur et al. 1997), ovine (Clop et al. 2006), canine (Mosher et al. 2007) and human (Schuelke et al. 2004), and these also display a phenotype of substantially increased muscle mass. Conversely, upregulation of myostatin is associated with pathological conditions characterised by muscle wasting, notably sarcopenia and cachexia arising from late-stage cancer, chronic kidney failure and congestive heart failure (Elkina et al. 2011, Elliott et al. 2012).

Apart from skeletal muscle, myostatin has also been implicated in the regulation of cardiomyocyte and adipocyte function (review: Elliott et al. 2012), Moreover, investigations into the expression and potential functional role(s) of myostatin in reproductive organs including the human ovary have recently been reported (Chang et al. 2015, 2016a,b, Fang et al. 2015). 
Myostatin signals through the activin receptor type 2B (ACTR2B), forming a signalling complex with ACVR1B (ALK4) and/or TGFBR1 (ALK5) that activates an intracellular Smad 2/3-dependent signal transduction pathway. Myostatin receptor activation can also signal in a Smad-independent manner via activation of MAPK and inhibition of Akt pathways (Rebbapragada et al. 2003). Binding of myostatin to its signalling receptors is modulated by follistatin (Amthor et al. 2004). Follistatin was initially identified as a secreted activin-binding protein but has since been shown to bind several other TGF- $\beta$ ligands including BMP-2,-4,-6 and -7 (Fainsod et al. 1997, lemura et al. 1998, Glister et al. 2004). Follistatin-null mice show decreased muscle mass (Matzuk et al. 1995) likely arising from diminished antagonism of myostatin signalling. Conversely, transgenic overexpression of follistatin promotes a hypermuscular phenotype resembling that of myostatin-null mice (Lee \& McPherron 2001).

Global microarray studies of the bovine ovary revealed that myostatin mRNA is expressed in follicular granulosa (Skinner et al. 2008, Glister et al. 2014, Hatzirodos et al. 2014b) and theca cells (Glister et al. 2013, Hatzirodos et al. 2014a) although studies to confirm expression and explore the potential functional role(s) of myostatin in the bovine ovary have not been reported. Myostatin mRNA expression has also been documented in human reproductive tissues including ovary (Chang et al. 2015), myometrium (Islam et al. 2014) and trophoblast (Peiris et al. 2014) and recent evidence from studies on luteinised granulosa cells supports various functional roles. For instance, treatment of human granulosa-lutein cells with myostatin downregulated expression of steroidogenic acute regulatory protein $(S T A R)$ and reduced progesterone secretion, whilst increasing cytochrome P450 aromatase (CYP19A1) expression, FSHR expression and oestradiol secretion (Chang et al. 2015, 2016a, Fang et al. 2015). An anti-proliferative effect of myostatin on human granulosa-lutein cells was also reported (Chang et al. 2016b). To our knowledge, there have been no reports on effects of myostatin on non-luteinised granulosa cells, nor on theca cells from any species.

Given the paucity of information on the ovarian expression and possible intraovarian role(s) of myostatin, particularly in relation to actions on nonluteinised follicular cells, the aims of the present study were to: (1) examine mRNA expression profiles for myostatin, its signalling receptors and binding protein (follistatin; FST) in granulosa (GC) and theca (TC) cells across different stages of bovine antral follicle development; (2) use non-luteinised bovine GC and TC culture models to investigate whether myostatin affects steroid production; (3) determine whether the effect of myostatin can be attenuated by follistatin; (4) investigate whether thecal and granulosal expression of myostatin
mRNA is modulated by gonadotropins and several intrafollicular factors implicated in the regulation of follicular steroidogenesis.

\section{Materials and methods}

\section{Relative expression of myostatin, follistatin and myostatin receptor $m R N A s$ in developing bovine antral follicles}

Relative mRNA expression for myostatin (MSTN), myostatin receptors (ACVR2B, ACVR1B and TGFBR1) and follistatin (FST) in theca and granulosa layers from bovine antral follicles was determined using RT-qPCR. Ovaries from randomly cycling cattle were obtained from an abattoir (Anglo Beef Processors, Guildford, UK) and selected for follicle dissection as described previously (Glister et al. 2001, 2004, 2010). Briefly, antral follicles of diameter $3-18 \mathrm{~mm}$ were dissected out and sorted by size into small $(3-6 \mathrm{~mm} ; n=30)$, medium $(7-10 \mathrm{~mm} ; n=43)$ and large $(11-18 \mathrm{~mm} ; n=37)$ categories. For each follicle, GC and TC layers were retrieved for RNA extraction and follicular fluid recovered for steroid hormone analysis. Follicles in the large $(11-18 \mathrm{~mm})$ category were subdivided retrospectively into large oestrogen-active (LEA; E:P ratio $>1$ ) and large oestrogen-inactive ( $\mathrm{LEl} ; \mathrm{E}: \mathrm{P}$ ratio $<1$ ) categories according to their intrafollicular ratio of oestrogen to progesterone (E:P ratio). Isolated GC and TC were homogenised in $0.5 \mathrm{~mL}$ of Tri-reagent (Sigma UK Ltd, Poole) and stored at $-80^{\circ} \mathrm{C}$ for subsequent RNA purification. The number of GC and TC RNA extracts recruited to the study ( $n=82$ GC samples; $n=87$ TC samples; see Fig. 1 for $n$-values for individual follicle categories) was lower than the number of extracts processed because samples indicating $>5 \% \mathrm{GC} / \mathrm{TC}$ cross contamination were rejected during an initial quality control screen. This involved a RT-qPCR-based comparison of relative transcript abundance of four GC/TC-specific 'marker' transcripts (FSHR and CYP19A1 for GC, CYP17A1 and INSL3 for TC) each normalised to $\beta$-actin transcript abundance (data not shown).

\section{Primary granulosa and theca cell culture models}

Ovaries from randomly cycling cattle were collected from a local abattoir. As described previously (Glister et al. 2001, 2005), GC and TC were isolated from $4-6 \mathrm{~mm}$ diameter follicles, plated out in either 96-well $(75,000$ cells/well; for steroid secretion experiments) or 24-well (250,000 cells/ well; for RNA extraction experiments) plates and cultured for 7 days. To preserve a non-luteinised cellular phenotype (Gutierrez et al. 1997, Campbell et al. 1998, Glister et al. 2001, 2005, Sahmi et al. 2006) chemically defined serum-free media was used throughout the culture period. This consisted of McCoy's 5A modified medium supplemented with $1 \%$ $(\mathrm{v} / \mathrm{v})$ antibiotic-antimycotic solution, $10 \mathrm{ng} / \mathrm{mL}$ bovine insulin, $2 \mathrm{mM}$ L-glutamine, $10 \mathrm{mM}$ Hepes, $5 \mu \mathrm{g} / \mathrm{mL}$ apotransferrin, $5 \mathrm{ng} /$ $\mathrm{mL}$ sodium selenite, $0.1 \%$ BSA. In the case of GC cultures, media was also supplemented with $10^{-7} \mathrm{M}$ androstenedione as aromatase substrate (all media and supplements were purchased from Sigma). Media were replenished and treatments added on days 2 and 4 (see below). Cultures were terminated 
Table 1 List of primers used for quantitative RT-PCR.

\begin{tabular}{|c|c|c|c|c|}
\hline Target & Accession number & $\begin{array}{l}\text { Forward primer } \\
5^{\prime} \text { to } 3^{\prime}\end{array}$ & $\begin{array}{l}\text { Reverse primer } \\
5^{\prime} \text { to } 3^{\prime}\end{array}$ & Amplicon size (bp) \\
\hline LHCGR & NM_174381.1 & ATTGCCTCAGTCGATGCCCAGACC & AAAAAGCCAGCCGCGCTGC & 92 \\
\hline STAR & NM_174189 & TTTTTTCCTGGGTCCTGACAGCGTC & ACAACCTGATCCTTGGGTTCTGCACC & 103 \\
\hline CYP11A1 & NM_176644 & CAGTGTCССТСТGСТСАACGTCC & TTATTGAAAATTGTGTCCCATGCGG & 99 \\
\hline HSD3B1 & NM_174343.2 & GCCACСТAGTGACTCTTTCCAACAGCG & TGGTTTTCTGCTTGGCTTCCTCCC & 111 \\
\hline FSHR & NM_174061.1 & GCCAGССТСАССТАССССАGC & AATTGGATGAAGGTCAGAGGTTTGCC & 75 \\
\hline CYP17A1 & NM_174304 & GACAAAGGCACAGACGTTGTGGTCA & TGATCTGCAAGACGAGACTGGCATG & 301 \\
\hline CYP19A1 & NM_174365 & TCTGTССССАСТGАATССТССТGG & GGGTTTCATGGTGCTGTGTGGC & 102 \\
\hline MSTN & NM_001001525.2 & GTTCGATGTCCAGAGAGATGCCAGC & ACTTGCGTTAGAAGATCAGACTCCGTGG & 114 \\
\hline$A C T B$ & NM_173979.3 & ATCACCATCGGCAATGAGCGGTTC & CGGATGTCGACGTCACACTTCATGA & 128 \\
\hline
\end{tabular}

on day 7 when conditioned media were retained for hormone assays and viable cell number was determined by neutral red uptake assay as described elsewhere (Glister et al. 2001).

\section{Effects of myostatin on granulosal and thecal steroid secretion and viable cell number}

Recombinant human myostatin (R\&D Systems; 94\% amino acid sequence homology with bovine myostatin) was added to wells to give final concentrations of $0.08,0.4,2,10,50$ and $100 \mathrm{ng} / \mathrm{mL}$ in the presence and absence of gonadotropin (FSH or LH). Highly purified ovine FSH (oFSH 19SIAPP) and LH (oLH-S-16) were provided by the NHPP (Torrance, CA, USA). In GC cultures, FSH was used at a final concentration of $0.3 \mathrm{ng} / \mathrm{mL}$, shown previously to elicit optimal oestradiol secretion (Glister et al. 2001, 2004). GC were also treated with myostatin $(100 \mathrm{ng} / \mathrm{mL})$ in the presence and absence of LR3 IGF-1 analogue (Sigma; 10 and $50 \mathrm{ng} / \mathrm{mL}$ ) since IGF-1 is also a potent stimulator of oestradiol secretion (Gutierrez et al. 1997, Glister et al. 2001). In the case of TC cultures, LH was used at a final concentration of $150 \mathrm{pg} / \mathrm{mL}$, shown previously to elicit maximal androstenedione secretion (Glister et al. 2005). Control wells received an equivalent volume of culture medium as vehicle.

\section{Can follistatin neutralise the effect of myostatin on thecal androstenedione secretion?}

To examine whether follistatin can neutralise the suppressive effects of myostatin on thecal androgen secretion, TC were treated with myostatin $(100 \mathrm{ng} / \mathrm{mL})$ in the presence/absence of recombinant human follistatin-288 (R\&D systems; 96\% amino acid sequence homology with bovine follistatin) at 0.25 and $1.25 \mu \mathrm{g} / \mathrm{mL}$. These concentrations were shown previously to reverse the effects of $50 \mathrm{ng} / \mathrm{mL}$ activin and BMP6 on bovine GC (Glister et al. 2004).

\section{Effect of myostatin on granulosal expression of steroidogenic pathway components}

To evaluate the effects of myostatin on expression of key transcripts involved in steroidogenesis (CYP11A1, HSD3B1, CYP19A1, FSHR) GC were cultured in 24-well plates (250,000 cells/well) and exposed to fixed concentrations of myostatin $(100 \mathrm{ng} / \mathrm{mL})$ in the presence and absence of an optimal concentration of FSH $(300 \mathrm{pg} / \mathrm{mL})$. At the end of culture, media were removed and cell lysates were prepared for total RNA extraction and RT-qPCR analysis.

\section{Do gonadotropins and other factors modulate MSTN expression by cultured GC and TC?}

GC ( $n>4$ independent batches of cells) plated out in 24-well plates were cultured in the presence/absence of FSH (300 pg/ $\mathrm{mL}$ ) and several other intrafollicular factors shown previously to modulate steroidogenesis at the concentrations used here, including LR3 IGF-1 analogue at $10 \mathrm{ng} / \mathrm{mL}$ (Glister et al. 2001), TNF $\alpha$ at $10 \mathrm{ng} / \mathrm{mL}$ (Glister et al. 2014) and DHT at $100 \mathrm{nM}$ (Wu et al. 2011, Hasegawa et al. 2017). RNA was harvested at the end of culture for evaluation of relative gene expression by RT-qPCR. TC ( $n=9$ independent batches of cells) plated out in 96-well plates were treated with $\mathrm{LH}(150 \mathrm{pg} / \mathrm{mL})$ in the presence/absence of BMP6 $(10 \mathrm{ng} / \mathrm{mL})$ shown previously to suppress thecal androgen production (Glister et al. 2005, 2013).

\section{RNA isolation, CDNA synthesis and real-time PCR}

Total RNA was isolated using Tri-reagent as described previously (Glister et al. 2010). cDNA was synthesised from $1 \mu \mathrm{g}$ of RNA using the AB High Capacity cDNA synthesis kit (Thermo Fisher Scientific; used according to manufacturer's protocol) in a $20 \mu \mathrm{L}$ reaction primed with random hexamers. PCR primers (see Table 1) were designed using Primer-

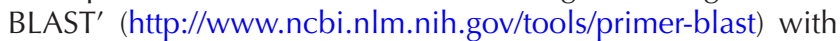
BLAST specificity checking against all known bovine (Bos taurus) transcripts to exclude potential amplification of offtarget sequences. Primer pairs were also validated using agarose gel electrophoresis to demonstrate amplification of a single product of the predicted size. Melt curve analyses was included in each PCR assay to confirm the amplification of a single product in each sample. cDNA template log-dilution curves were used to demonstrate satisfactory PCR efficiency and linearity. PCR assays were carried out in a volume of $14 \mu \mathrm{L}$ containing $5 \mu \mathrm{L}$ cDNA template, $1 \mu \mathrm{L}$ each forward and reverse primers (final concentration $0.36 \mu \mathrm{M}$ ) and $7 \mu \mathrm{L}$ QuantiTect SYBR Green QPCR 2x Master Mix (Qiagen). Samples were processed on a StepOne Plus thermal cycler (Applied Biosystems) with cycling conditions: $15 \mathrm{~min}$ at $95^{\circ} \mathrm{C}$ (one cycle only) followed by $15 \mathrm{~s}$ at $95^{\circ} \mathrm{C}$ and $1 \mathrm{~min}$ at $60^{\circ} \mathrm{C}$ for 40 cycles. The $\Delta \Delta$ Ct method (Livak \& Schmittgen 2001) was used to compare the relative abundance of each mRNA transcript. Ct values for each transcript in a given sample were 
first normalised to the corresponding $\beta$-actin $\mathrm{Ct}$ value (i.e. $\Delta$ Ct value). In the case of theca and granulosa tissue samples, $\Delta \mathrm{Ct}$ values for each transcript in a given sample were then normalised to the mean $\Delta \mathrm{Ct}$ value for that transcript in all tissue samples. Resultant $\Delta \Delta$ Ct values were converted to folddifferences using the formula: fold-difference $=2^{(-\Delta \Delta C t)}$. In the case of cell culture experiments, $\Delta$ Ct values were normalised to the corresponding $\Delta \mathrm{Ct}$ value for vehicle-treated control cells. $\Delta \Delta \mathrm{Ct}$ values were then converted to fold-differences using the formula: fold-difference $=2^{(-\Delta \Delta C t)}$.

\section{Steroid hormone assays}

Steroid concentrations were determined by competitive ELISA as described previously (Glister et al. 2010, 2013, 2014). The progesterone assay had a detection limit of $20 \mathrm{pg} / \mathrm{mL}$ and intra- and inter-assay CVs were $8 \%$ and $10 \%$ respectively. The androstenedione ELISA had a detection limit of $30 \mathrm{pg} / \mathrm{mL}$ and intra- and inter-assay CVs were 7 and $10 \%$ respectively. The oestradiol ELISA had a detection limit of $15 \mathrm{pg} / \mathrm{mL}$ and intraand inter-assay $\mathrm{CV}$ s were $6 \%$ and $9 \%$ respectively.

\section{Immunohistochemistry}

Bovine ovaries were dissected into segments and fixed in formalin for $48 \mathrm{~h}$, before being dehydrated through an alcohol series, embedded in wax and sectioned $(5 \mu \mathrm{m})$ onto Superfrost charged slides (VWR, Lutterworth, UK). Sections were dewaxed and rehydrated prior to boiling in citrate buffer $(10 \mathrm{mM}$ citric acid, pH6.0), blocking of endogenous peroxidase $\left(3 \% \mathrm{H}_{2} \mathrm{O}_{2}\right.$ in methanol) and blocking of nonspecific binding with $20 \%$ normal goat serum (NGS, Vector Laboratories Ltd, Peterborough, UK). After this, sections were incubated overnight at $4{ }^{\circ} \mathrm{C}$ in rabbit antibody against GDF8 (1:200; sc-28910, Santa Cruz) diluted in 2\% NGS. Control sections were incubated with normal rabbit serum $(1: 200)$ diluted in 2\% NGS. Primary antibody binding was detected using biotinylated goat anti-rabbit diluted $1: 250$ in $2 \%$ NGS and Vector Elite ABC reagents (Vector), prepared as per manufacturer's instructions. Visualisation of bound antibodies was achieved using 3,3'-diaminobenzidine tetrahydrochloride (DAB; Vector), prior to slides being counterstained with haematoxylin, dehydrated through an alcohol series and mounted with coverslips using DPX mounting medium. Sections were imaged using a Zeiss Axioscop 2 microscope and AxioCam digital camera.

\section{Statistical analysis}

Steroid concentrations were log-transformed prior to statistical analysis to reduce the heterogeneity of variance. RT-qPCR data were analysed as $\Delta \Delta$ Ct values (i.e. $\log _{2}$ values) before conversion to fold-difference values for graphical presentation of relative transcript abundance. ACTB was used as the normalisation control and showed uniform expression level across experimental groups being compared. Results were evaluated using one- and/or two-way ANOVA and, where indicated, post hoc pairwise comparisons were made using Fisher's protected least significant difference test. Results of cell culture experiments are based on a minimum of three replicate experiments using independent batches of cells (see figure legends for numbers of replicates).

\section{Results}

Relative expression of myostatin, follistatin and myostatin receptors in theca and granulosa layers

\section{Myostatin}

MSTN mRNA expression was found in both TC and GC of all antral follicles examined and overall expression level was higher in TC than GC (Fig. 1A). Interestingly, whilst MSTN expression level in TC was uniform across antral follicle development, expression in GC fell $\sim 15$-fold to a nadir in large oestrogen-active (LEA) follicles. However, a higher expression level was maintained in GC of large oestrogen-inactive (LEI) follicle. (Fig. 1A). Immunohistochemistry confirmed myostatin protein expression in both TC and GC of antral follicles (Fig. 2). In addition, myostatin immunoreactivity was evident in preantral follicles and in vascular smooth muscle cells. Both oocytes and granulosa cells of primordial, primary and secondary follicles exhibited positive immunostaining for myostatin (Fig. 2).

\section{Follistatin}

FST mRNA expression was found in both TC and GC at all stages of follicle development examined with much higher expression levels in GC than TC (Fig. 1B). Interestingly, the expression of FST in GC sharply increased in LEA follicles but remained low in LEI follicles; this was opposite to what was observed for MSTN.

\section{Myostatin receptors ( $A C V R 2 B, A C V R 1 B$ and TGFBR1)}

ACVR1B, TGFBR1 and ACVR2B mRNA expression was found in both TC and GC at all stages of follicle development examined. The expression of $A C V R 2 B$ and $A C V R 1 B$ was generally higher in GC than TC whilst TGFBR 1 expression levels were broadly similar in the two cell types. No notable changes in cell-specific patterns of expression of these receptors between each stages of follicle development were evident (Fig. 1C, D and $\mathrm{E}$ respectively).

\section{Effect of myostatin on basal and FSH-induced steroid secretion by GC}

Myostatin promoted a marked increase in basal oestradiol secretion by cultured GC $(\sim 12$-fold; $P<0.0001$; Fig. $3 \mathrm{~A})$ but did not modulate the $>30$-fold increase in oestradiol secretion elicited by FSH. Myostatin suppressed both basal $(P<0.01)$ and $\mathrm{FSH}$-induced $(P<0.001)$ progesterone secretion (Fig. 3B). In addition, myostatin promoted a modest though significant increase in cell number under 


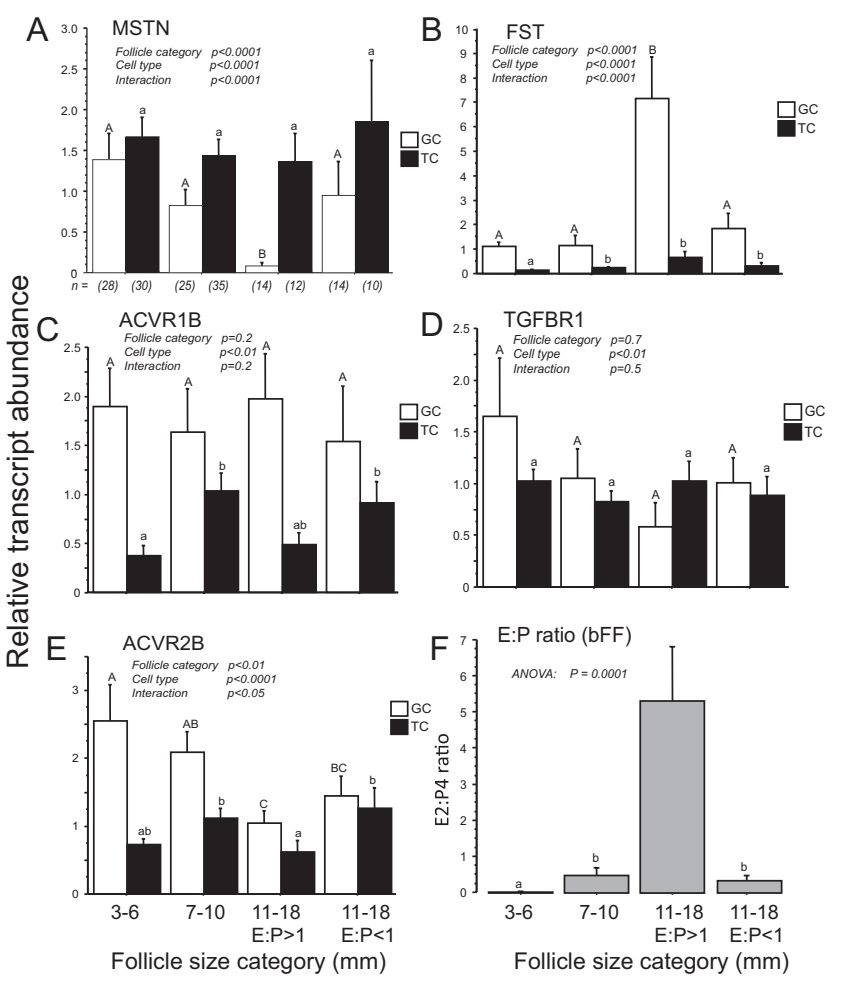

Figure 1 Relative abundance of mRNA transcripts for (A) MSTN, (B) FST, (C) ACVR1B, (D) TGFBR1 and (E) ACVR2B in theca and granulosa layers of small $(3-6 \mathrm{~mm})$, medium $(7-10 \mathrm{~mm})$ and large $(11-18 \mathrm{~mm}$ ) bovine antral follicles. Large follicles are subdivided into oestrogen-active $(\mathrm{E}: \mathrm{P}$ ratio $>1)$ and oestrogen-inactive $(\mathrm{E}: \mathrm{P}$ ratio $<1)$ categories referred to as LEA and LEI follicles, respectively. Intrafollicular E:P ratios for each follicle category are shown in panel (F). Numbers in parenthesis in panel A are $n$-values for each group. Values are mean \pm S.E.M. and summarised two-way ANOVA results are shown. Within each cell type means without a common letter are significantly different $(P<0.05)$.

basal conditions $(\sim 20 \%$ increase; $P<0.001)$, but not under FSH-stimulated conditions (Fig. 3C).

\section{Effects of myostatin on GC expression of steroidogenesis-related transcripts}

The stimulatory action of myostatin on basal oestradiol secretion was accompanied by a $\sim 10$-fold increase in CYP19A1 expression level $(P<0.05$; Fig. 3D). Concomitantly, a reduction in CYP11A1 and HSD3B1 expression level was observed $(P<0.05$; Fig. $3 \mathrm{E}$ and $\mathrm{F})$ that mirrored the myostatin-induced decrease in progesterone secretion. Myostatin did not affect FSHR expression (data not shown).

\section{Effect of myostatin on basal and IGF1-induced secretion of oestradiol and progesterone by GC}

Figure 4 confirms the stimulatory effect of myostatin treatment $(100 \mathrm{ng} / \mathrm{mL})$ on basal oestradiol secretion by GC. However, myostatin did not modulate the

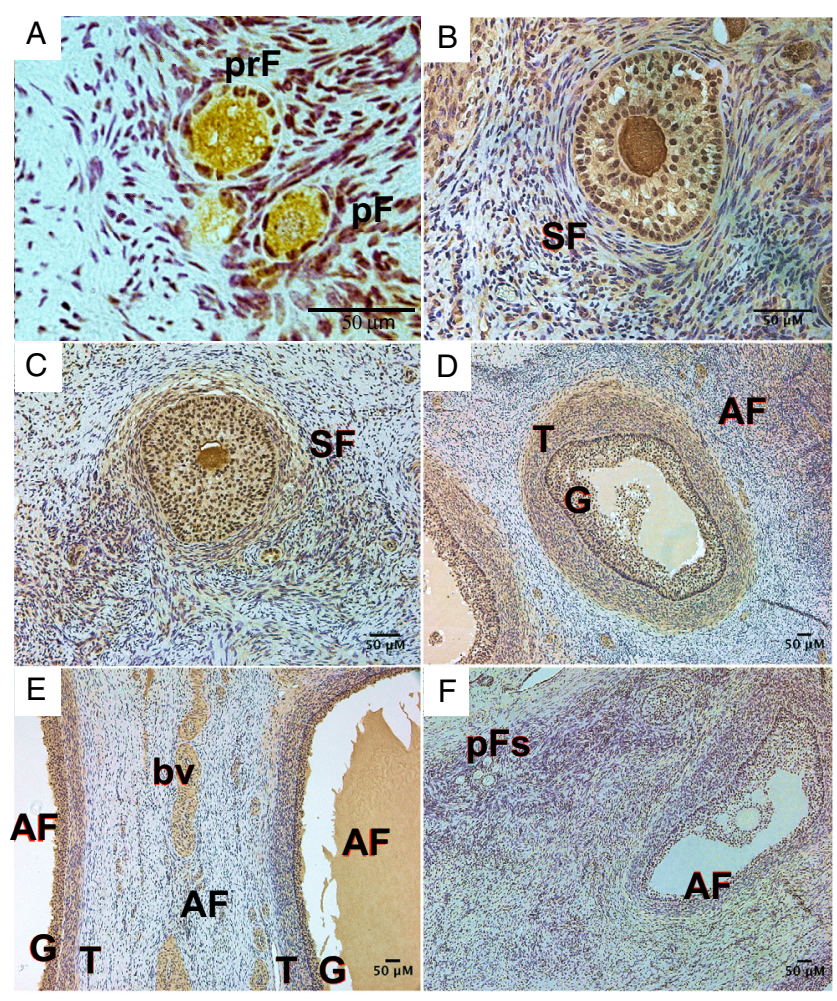

Figure 2 Immunohistochemical staining of bovine ovary sections showing myostatin immunoreactivity (brown) in oocyte and granulosa cells of primordial (pF) and primary (PrF) follicles (A), secondary (SF) follicles $(B, C)$ and in thecal $(\mathrm{T})$ and granulosal $(\mathrm{G})$ layers of antral follicles (AF) (D and E). Myostatin immunoreactivity was also evident in vascular smooth muscle cells (bv) (E). No staining was observed in control sections treated with normal rabbit serum instead of primary antibody (F).

stimulatory effect of the LR3-IGF1 analogue on oestradiol secretion or viable cell number. Myostatin reduced both basal and IGF-induced progesterone secretion $(P<0.05)$ but did not modify the IGF-induced increase in viable cell number.

\section{Effects of FSH, LR3 IGF-1, TNF $\alpha$ and DHT on expression of MSTN mRNA by cultured GC}

Figure 5 shows that treatment of cultured GC with FSH elicited a 50-fold upregulation of CYP19A1 expression $(P<0.05)$ and oestradiol secretion but did not affect MSTN expression. Treatment with IGF-1 analogue also promoted a marked increase in CYP19A1 expression $(\sim 10$-fold; $P<0.05)$ and oestradiol secretion that was accompanied by a $60 \%$ reduction in MSTN expression $(P<0.05)$. Treatment with TNF $\alpha$ had no effect on basal CYP19A1 expression but abolished $\mathrm{FSH}$-induced upregulation of CYP19A1 expression and oestradiol secretion. TNF $\alpha$ suppressed MSTN expression by $\sim 80 \%(P<0.05)$ under both basal and $\mathrm{FSH}$-stimulated conditions. Treatment with DHT did not affect the expression of either MSTN or CYP19A1. 

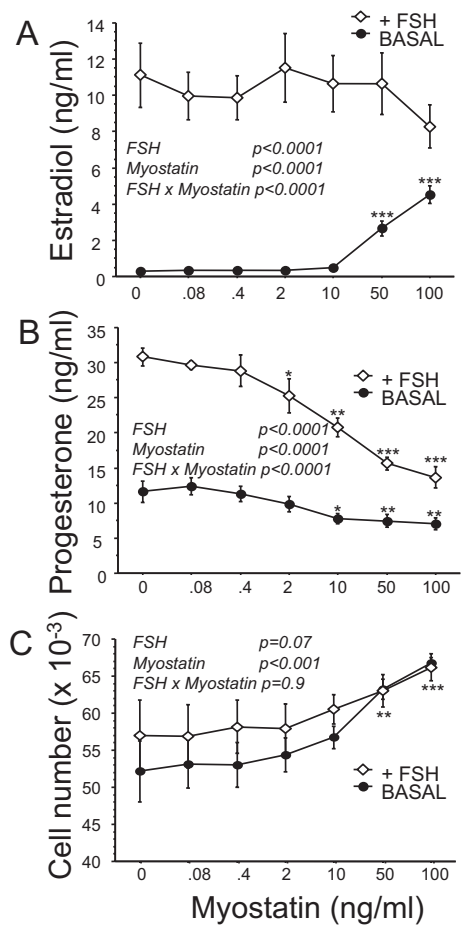

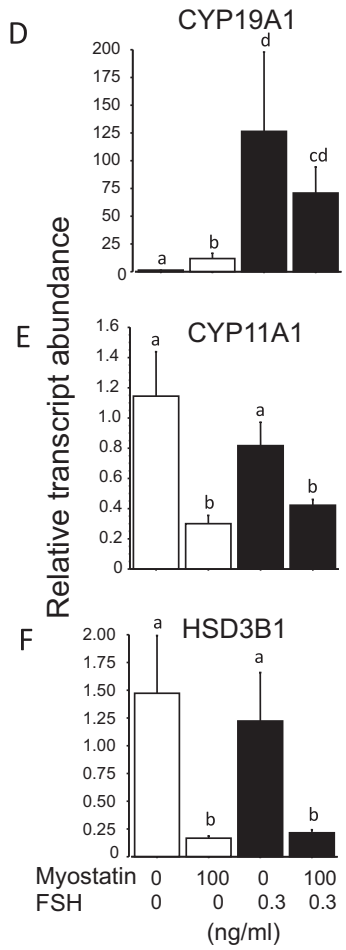

Figure 3 Effect of myostatin on basal and FSH-induced secretion of (A) oestradiol and (B) progesterone by bovine granulosa cells and on (C) viable cell number; Panels (D, E and F) show the effect of myostatin \pm FSH on expression of CYP19A1, CYP11A1 and HSD3B1 $\mathrm{mRNA}$, respectively. Values are means \pm S.E.M. $(n=5$ independent cultures). Results of two-way ANOVA are summarised; $* P<0.01$, ${ }^{* *} P<0.01{ }^{* * *} P<0.001$ compared to respective control with zero myostatin (panels $A, B, C)$. In panels $(D, E$ and $F$ ) means without a common letter are significantly different $(P<0.05)$.

\section{Effects of myostatin on thecal steroid secretion and viable cell number}

Myostatin suppressed androstenedione secretion in a dose-dependent manner $(P<0.001)$ with an $\mathrm{IC}_{50}$ of $\sim 10 \mathrm{ng} / \mathrm{mL}$ under LH-stimulated conditions (Fig. 6A). No effect of myostatin on progesterone secretion was observed (Fig. 6B). Viable cell number was increased $(\sim 25 \% ; P<0.0001)$ by myostatin under both basal and LH-stimulated conditions (Fig. 6C). LH increased both androstenedione and progesterone secretion but did not affect viable cell number.

\section{Can follistatin neutralise the effect of myostatin on androstenedione secretion?}

Treatment of cells with myostatin alone decreased androstenedione secretion by $\sim 80 \%(P<0.000$; Fig. 7$)$. Co-treatment with follistatin partially reversed this inhibitory action $(P<0.001)$. Treatment with follistatin alone tended to increase androstenedione secretion, but the effect was not statistically significant.
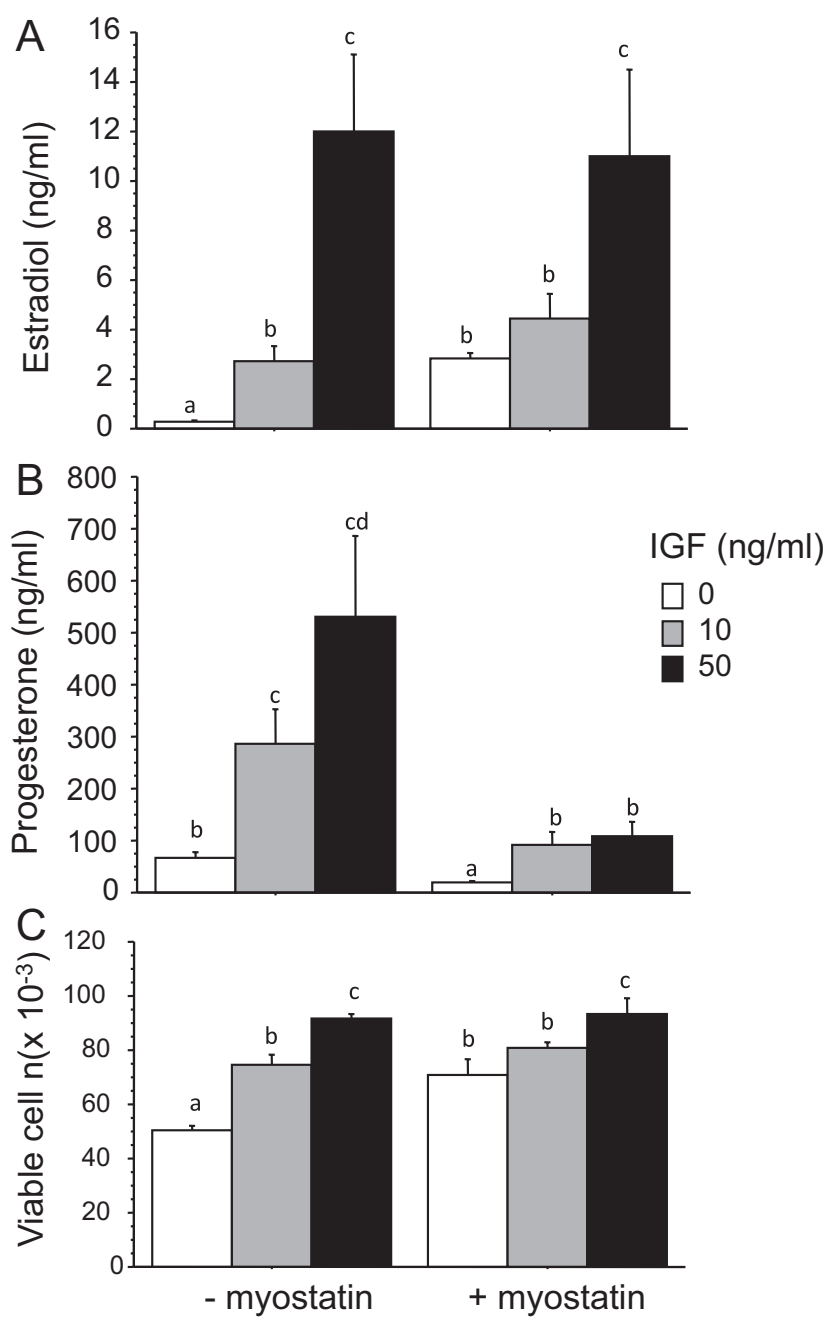

Figure 4 Effect of myostatin on basal and LR3 IGF-1-induced secretion of (A) oestradiol and (B) progesterone by bovine granulosa cells and on (C) viable cell number. Values are means \pm S.E.M. $(n=3$ independent cultures). Means without a common letter are significantly different $(P<0.05)$.

\section{Effects of LH and BMP6 on MSTN mRNA expression by cultured TC}

Figure 8 shows that treatment of cultured TC with $\mathrm{LH}$ elicited a four-fold increase in CYP17A1 expression and androstenedione secretion that was accompanied by a $40 \%$ suppression of MSTN expression $(P<0.05)$. Treatment with BMP6 profoundly suppressed basal and $\mathrm{LH}$-induced CYP17A1 expression and androstenedione secretion. Whilst BMP6 alone did not affect MSTN expression, it reversed the suppressive effect of $\mathrm{LH}$ on MSTN expression.

\section{Discussion}

In this study, we first provide novel information on the spatio-temporal pattern of mRNA expression of 

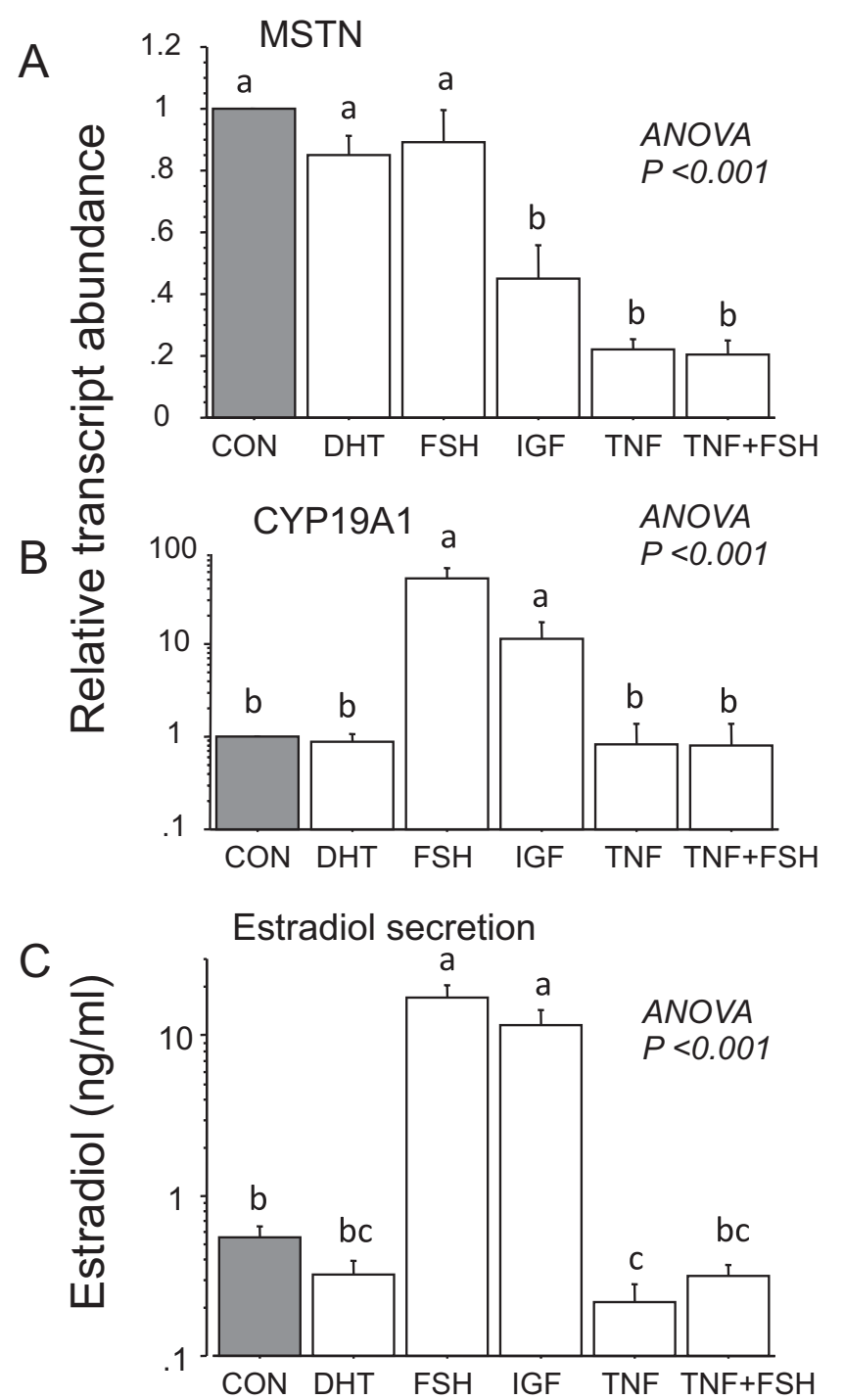

Figure 5 Effect of different treatments known to modulate GC steroidogenesis on granulosal expression of (A) MSTN and (B) CYP19A1 and on (C) secretion of oestradiol. Values are means \pm S.E.M. ( $n=4$ independent cultures); Means without a common letter are significantly different $(P<0.05)$.

myostatin, its signalling receptors and the binding protein (FST), at different stages of bovine antral follicles development. Expression of mRNA for MSTN and its receptors was found in both GC and TC at all antral follicle stages examined, consistent with and extending previous evidence from global microarray studies (Skinner et al. 2008, Glister et al. 2013, 2014, Hatzirodos et al. 2014a,b). Immunohistochemistry confirmed corresponding expression of myostatin protein in follicular granulosa and theca interna layers of antral follicles. Moreover, myostatin immunoreactivity was observed at earlier follicle stages than those we analysed for mRNA expression, with positive staining in both oocytes and GC of primordial, primary and secondary follicles and both GC and TC of late preantral

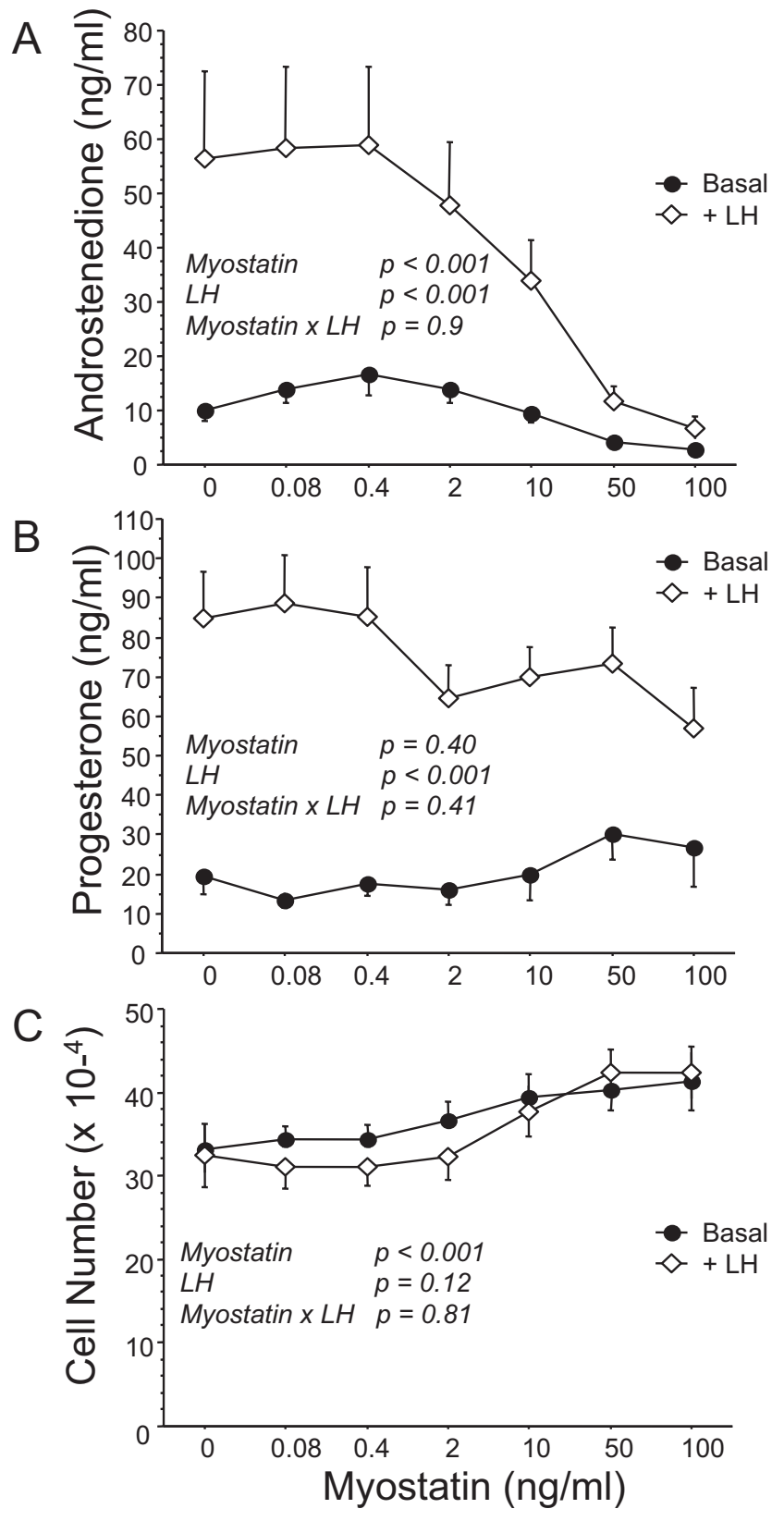

Figure 6 The effects of myostatin on basal and LH-induced secretion of (A) androstenedione and (B) progesterone by bovine theca cells. Panel $(C)$ shows effects on viable cell number. Values are mean \pm S.E.M. ( $n=12$ independent cultures); Two-way ANOVA $P$-values are shown.

and early antral follicles. The inverse mRNA expression pattern of MSTN and FST we observed in GC of large oestrogen-active follicles is of interest since follistatin is known to bind to and inhibit myostatin signalling (Lee \& McPherron 2001, Amthor et al. 2004), a finding confirmed in this study by its ability to attenuate the effect of myostatin on thecal androgen production. These results suggest, therefore, that GC-derived myostatin and follistatin interact to regulate ovarian follicle physiology. 


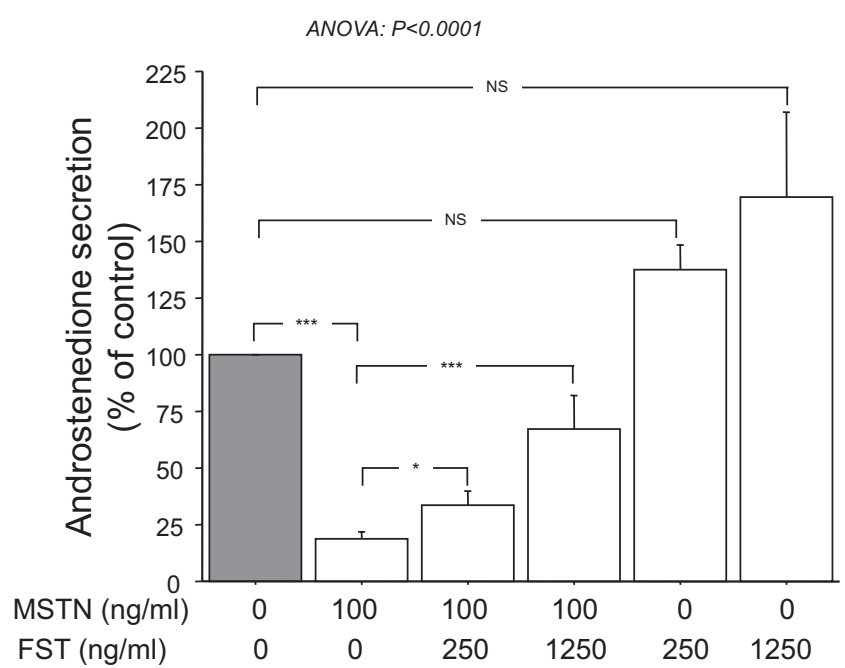

Figure 7 Ability of follistatin to antagonise myostatin-induced suppression of thecal androstenedione secretion. Values are means \pm S.E.M. ( $n=6$ independent cultures).

In particular, these observations suggest that autocrine/ paracrine signalling by GC-derived myostatin is attenuated in large healthy follicles (i.e. low myostatin/ high follistatin), such as those reaching the preovulatory stage of development. By contrast, at earlier antral follicle stages (i.e. high myostatin/low follistatin), myostatin signalling via a Smad $2 / 3$ dependent pathway may contribute to the suppression of thecal androgen production whilst upregulating granulosal oestradiol production and downregulating progesterone production. Thus, myostatin appears to act to prevent/ delay premature follicle maturation and luteinisation in a similar manner to that suggested previously for activins and BMPs (Findlay et al. 2002, Knight \& Glister 2006), both of which can attenuate thecal androgen production, enhance granulosal oestrogen output whilst suppressing granulosal progesterone output.

The present results from experiments on nonluteinised ovarian cell models clearly support the above with myostatin suppressing androgen secretion by theca cells. In the case of granulosa cells, myostatin enhanced basal CYP19A1 expression and oestradiol secretion whilst suppressing CYP11A1 and HSD3B1 expression and secretion of progesterone. In addition, treatment of human granulosa-lutein cells with myostatin was recently reported to enhance $\mathrm{FSH}$-induced upregulation of aromatase/oestradiol production, whilst inhibiting LH-induced upregulation of STAR/progesterone production (Chang et al. 2016a). Moreover, the present study found that myostatin increased viable cell number in both TC and GC cultures suggesting a positive effect on cell proliferation and/or survival. This finding contrasts with a report that myostatin reduces proliferation of human granulosa-lutein cells, evidently by upregulating connective tissue growth factor
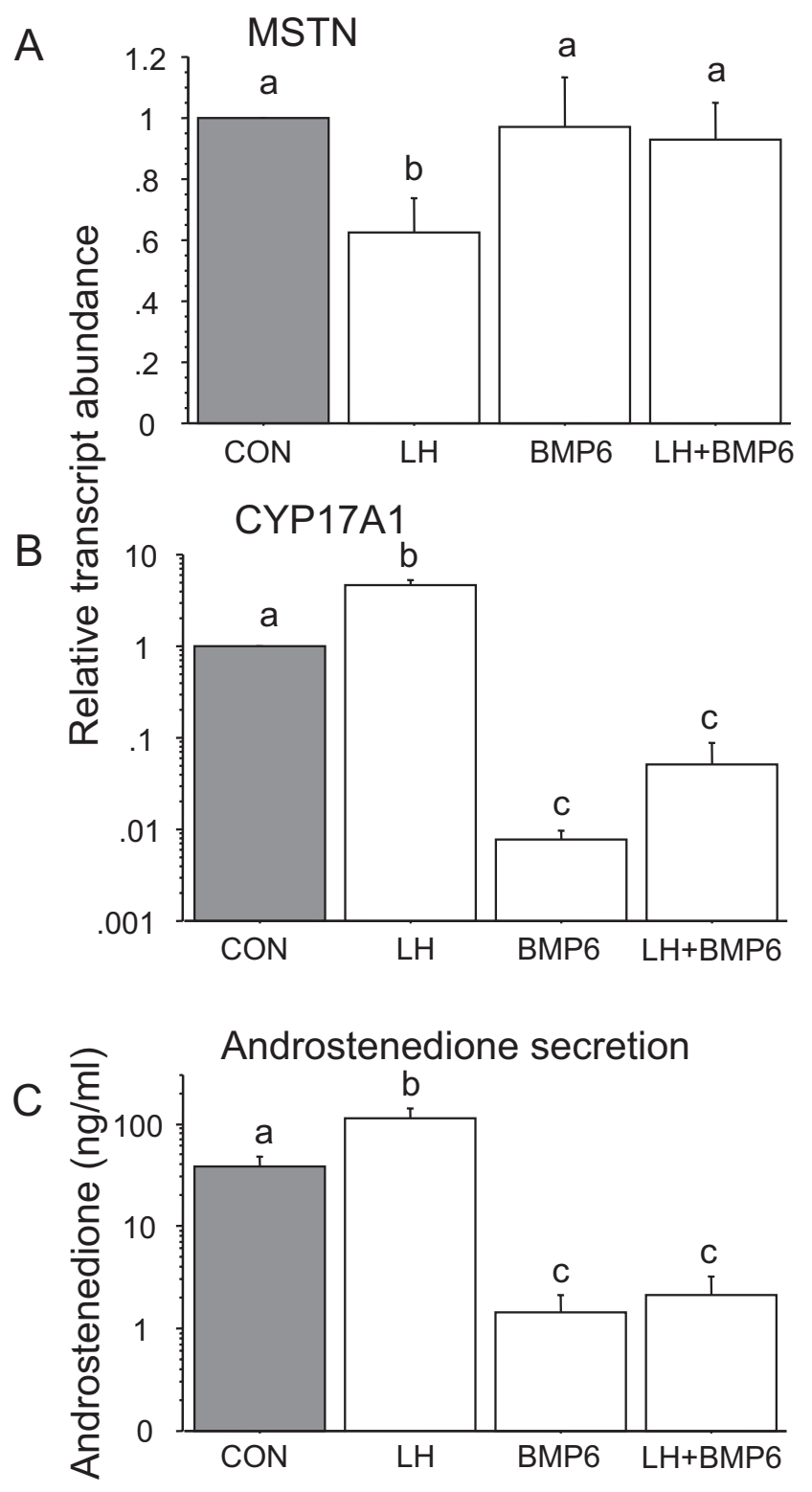

Figure 8 Effect of LH and BMP6 on thecal expression of (A) MSTN and (B) CYP17A1 and on (C) secretion of androstenedione. Values are means \pm S.E.M. ( $n=8$ independent cultures); means without a common letter are significantly different $(P<0.05)$.

expression (Chang et al. 2016b). The reason for this discrepancy is not known but may reflect the effect of luteinisation or a species difference.

An intrafollicular IGF system is firmly implicated in the autocrine/paracrine regulation of follicle development, steroidogenesis and dominant follicle selection (Campbell et al. 1995, Glister et al. 2001, Silva \& Price 2002, Webb et al. 2003). Like FSH, IGF-1 can upregulate granulosal oestradiol secretion; moreover, IGF-1 can augment follicular responsiveness to $\mathrm{FSH}$, providing a potential mechanism for selecting the dominant follicle from the cyclically-recruited growing cohort (Campbell et al. 1995, Webb et al. 2003). It was 
therefore pertinent to investigate whether myostatin affected the GC response to IGF-1 treatment. Although the results showed no effect on IGF-induced oestradiol production or cell number, myostatin increased basal oestradiol production and cell number whilst reducing basal and IGF-induced progesterone production. As such, these observations further support the notion that myostatin has a role to delay premature follicle maturation and luteinisation.

Whilst circulating or intrafollicular concentrations of myostatin in cattle have not been reported to our knowledge, serum concentrations of $10-20 \mathrm{ng} / \mathrm{mL}$ in cynomolgus monkey and human, $\sim 24 \mathrm{ng} / \mathrm{mL}$ in rat and $\sim 80 \mathrm{ng} / \mathrm{mL}$ in mouse have been documented (Furihata et al. 2016, Hedayati et al. 2016, Palandra et al. 2016). A myostatin concentration of $\sim 3 \mathrm{ng} / \mathrm{mL}$ has been reported for human follicular fluid (Chen et al. 2012). Since myostatin suppressed thecal androgen production and granulosal progesterone production in vitro with an IC50 value of $\sim 10 \mathrm{ng} / \mathrm{mL}$, it seems plausible that levels reaching the well-vascularised theca interna from peripheral blood could be sufficient to exert a regulatory action, regardless of the additional 'local' contribution (perhaps considerable?) of TC and/or GC-derived myostatin. On the other hand, given the greater diffusional barrier needed to reach the avascular granulosal layer, combined with the somewhat higher myostatin concentration $(\sim 50 \mathrm{ng} / \mathrm{mL})$ needed to upregulate GC oestradiol production, it is possible that GC are primarily responsive to locally produced myostatin acting in an autocrine/paracrine manner. The establishment of a bovine myostatin assay to allow comparison of endogenous concentrations in peripheral blood and ovarian follicular fluid of cattle in different physiological states and in follicles at different stages of development would be useful in this regard.

As a first step towards investigating which endocrine and local paracrine and/or autocrine signals regulate myostatin expression in bovine ovarian follicles, we found that an LH-induced increase in thecal CYP17A1 expression and androstenedione secretion was accompanied by reduced MSTN expression level, consistent with a negative autocrine/paracrine action of myostatin on thecal androgen production, and with the findings of our myostatin dose-response study. Indeed, it is possible that the stimulatory action of $\mathrm{LH}$ on thecal androgen production could be due, in part, to $\mathrm{LH}$-induced suppression of myostatin expression. The finding of a reduced MSTN mRNA abundance in TC producing more androgen could reflect increased androgen receptor-mediated signalling since raised androgen levels are also associated with decreased MSTN expression in rat skeletal muscle tissue (Mendler et al. 2007). However, another intraovarian growth factor, BMP6, shown here and elsewhere (Glister et al. 2005, 2013) to greatly reduce thecal CYP17A1 expression and androstenedione secretion, did not affect thecal
MSTN expression, casting doubt on androgen having a direct effect. Furthermore, treatment of cultured GC with the potent non-aromatisable androgen DHT had no effect on MSTN expression, suggesting an absence of androgen receptor-dependent regulation of granulosal MSTN expression. Consistent with previous findings (Gutierrez et al. 1997, Glister et al. 2001), treatment of GC with FSH and IGF analogue both promoted substantial increases in oestradiol secretion but only IGF analogue modulated MSTN expression, eliciting a $\sim 60 \%$ reduction. This suggests a possible interaction between IGF and myostatin signalling at the intrafollicular level that warrants further investigation. In skeletal muscle, IGF-1 is a prominent positive regulator of muscle cell proliferation and differentiation whilst myostatin opposes this action (Valdes et al. 2013). Despite this, IGF signalling upregulates myostatin expression in skeletal muscle tissue models, suggesting an inhibitory auto-regulatory loop (Yang et al. 2007, Kurokawa et al. 2009, Valdes et al. 2013).

The pro-inflammatory cytokine, TNF $\alpha$, is also expressed at the intraovarian level and is implicated in the regulation of follicle and luteal growth/regression and steroidogenesis (Sheldon et al. 2014, Samir et al. 2017). Consistent with earlier findings (Glister et al. 2014), we showed that TNF $\alpha$ abolished $\mathrm{FSH}$-induced upregulation of CYP19A1 and oestradiol secretion by GC. This was accompanied by a marked reduction in MSTN expression reinforcing the view that myostatin has a positive role in granulosal oestrogen production. In skeletal muscle models, activation of the TNF $\alpha$ pathway suppresses myogenesis but upregulates myostatin expression (Ono \& Sakamoto 2017). Moreover, IGF can reverse the TNF$\alpha$ induced suppression of myogenesis (Zhao et al. 2015) indicating interactions between positive (IGF1) and negative (myostatin, TNF- $\alpha$ ) regulators of myogenesis. Further studies are needed to decipher the regulatory signals that contribute to the regulation of myostatin

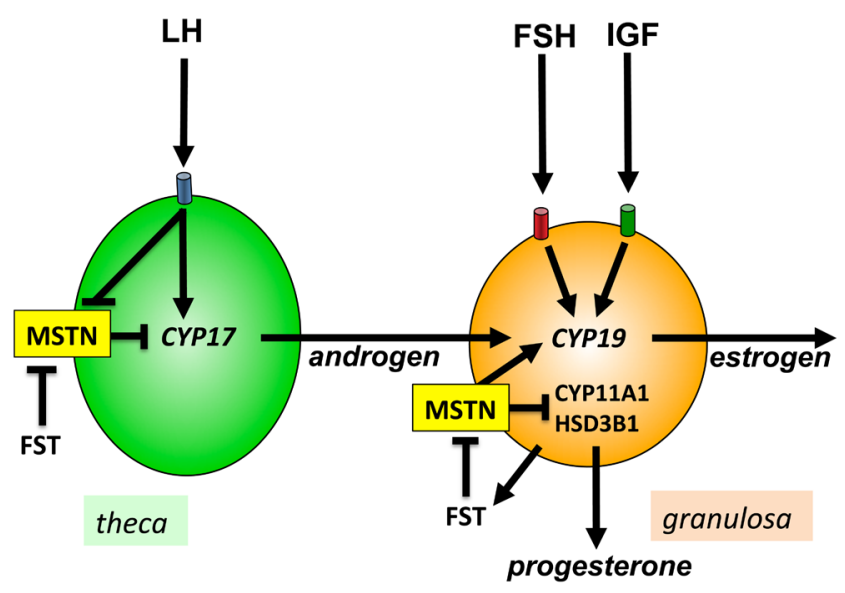

Figure 9 Schematic diagram illustrating potential involvement of systemic and/or locally produced myostatin in the modulation of thecal and granulosal steroidogenesis. 
expression by ovarian follicular cells and to place these in a physiological context.

With respect to myostatin-null mice, there are few, if any, references to their ovarian phenotype and the potential impact of the mutation on gonadal function and fertility is unknown to us. However, an in vivo study involving active immunisation of female mice against myostatin showed that the number of developing ovarian follicles in their female progeny was $\sim 50 \%$ lower than that of control mice, with a similar diminution in litter size (Liang et al. 2007). Double-muscled cattle with myostatin mutations reportedly show delayed puberty, reduced female fertility and a higher incidence of dystocia, and perinatal calf mortality/morbidity is associated with the large size of calves (McPherron \& Lee 1997). However, we are not aware of any studies examining whether perturbations in ovarian follicle dynamics or steroidogenesis occur in double-muscled cattle. Whilst information is currently lacking on the above, it is possible that the physiological actions of myostatin in the ovary are functionally redundant owing to compensatory effects of other TGF$\beta$ ligands (e.g. activins) that can signal via the same, or overlapping, receptors to elicit similar regulatory actions on theca and granulosa cells.

In summary, this study provides novel information on the expression of myostatin, its signalling receptors and the binding protein, follistatin, in theca and granulosa cells of developing bovine antral follicles. Myostatin expression in GC declined to a very low level in large oestrogenactive follicles in which expression of follistatin was maximal, suggesting attenuation of GC-derived myostatin signalling at this stage. Since myostatin suppressed thecal androgen production in a dose-dependent manner, an effect partially rescued by follistatin, it is hypothesised that attenuation of myostatin signalling in large antral follicles could facilitate thecal androgen production required as a substrate for granulosal aromatase enzyme and oestrogen synthesis. Paradoxically, however, myostatin was found to promote CYP19A1 expression and oestradiol production by granulosa cells under 'basal' conditions whilst suppressing CYP11A1 and HSD3B1 expression and progesterone production (see Fig. 9). Taken together, this suggests a role for myostatin in delaying follicle progression towards preovulatory maturation and luteinisation, in a manner similar to that suggested for granulosa-derived activin (Findlay et al. 2002, Knight \& Glister 2006). Further in-depth studies in other species, including whole animal models, are required to confirm and extend these in vitro observations based on bovine ovarian cell culture models. It is also speculated that muscle-derived myostatin conveyed to the ovary via the systemic circulation may contribute to the regulation of follicle function. In a similar manner, testicular steroidogenesis and gametogenesis may be influenced by circulating and/or locally produced myostatin although we are not aware of any studies, to date, examining this possibility.

\section{Declaration of interest}

The authors declare that there is no conflict of interest that could be perceived as prejudicing the impartiality of the research reported.

\section{Funding}

Supported by BBSRC (grant number BB/M001369 to PGK). W C was supported by a postgraduate scholarship from the Thai Ministry of Science and Technology.

\section{Acknowledgements}

The authors thank D Butlin and A D Simmonds for skilled technical assistance.

\section{References}

Amthor H, Nicholas G, McKinnell I, Kemp CF, Sharma M, Kambadur R \& Patel K 2004 Follistatin complexes Myostatin and antagonises Myostatinmediated inhibition of myogenesis. Developmental Biology 270 19-30. (https://doi.org/10.1016/j.ydbio.2004.01.046)

Campbell BK, Scaramuzzi RJ \& Webb R 1995 Control of antral follicle development and selection in sheep and cattle. Journal of Reproduction and Fertility Supplement 49 335-350.

Campbell BK, Baird DT \& Webb R 1998 Effects of dose of LH on androgen production and luteinization of ovine theca cells cultured in a serumfree system. Journal of Reproduction and Fertility 112 69-77. (https://doi. org/10.1530/jrf.0.1120069)

Campbell BK, Souza C, Gong J, Webb R, Kendall N, Marsters P, Robinson G, Mitchell A, Telfer EE \& Baird DT 2003 Domestic ruminants as models for the elucidation of the mechanisms controlling ovarian follicle development in humans. Reproduction Supplement $\mathbf{6 1}$ 429-443.

Chang HM, Fang L, Cheng JC, Klausen C, Sun YP \& Leung PC 2015 Growth differentiation factor 8 down-regulates pentraxin 3 in human granulosa cells. Molecular and Cellular Endocrinology 404 82-90. (https://doi. org/10.1016/j.mce.2015.01.036)

Chang HM, Fang L, Cheng JC, Taylor EL, Sun YP \& Leung PC $2016 \mathrm{a}$ Effects of growth differentiation factor 8 on steroidogenesis in human granulosa-lutein cells. Fertility and Sterility 105 520-528. (https://doi. org/10.1016/j.fertnstert.2015.10.034)

Chang HM, Pan HH, Cheng JC, Zhu YM \& Leung PCK 2016b Growth differentiation factor 8 suppresses cell proliferation by up-regulating CTGF expression in human granulosa cells. Molecular and Cellular Endocrinology 422 9-17. (https://doi.org/10.1016/j.mce.2015.11.009)

Chen MJ, Han DS, Yang JH, Yang YS, Ho HN \& Yang WS 2012 Myostatin and its association with abdominal obesity, androgen and follistatin levels in women with polycystic ovary syndrome. Human Reproduction 27 2476-2483. (https://doi.org/10.1093/humrep/des209)

Clop A, Marcq F, Takeda H, Pirottin D, Tordoir X, Bibe B, Bouix J, Caiment F, Elsen JM, Eychenne $\mathbf{F}$ et al. 2006 A mutation creating a potential illegitimate microRNA target site in the myostatin gene affects muscularity in sheep. Nature Genetics 38 813-818. (https://doi. org/10.1038/ng1810)

Elkina Y, von Haehling S, Anker SD \& Springer J 2011 The role of myostatin in muscle wasting: an overview. Journal of Cachexia, Sarcopenia and Muscle 2 143-151. (https://doi.org/10.1007/s13539-011-0035-5)

Elliott B, Renshaw D, Getting S \& Mackenzie R 2012 The central role of myostatin in skeletal muscle and whole body homeostasis. Acta Physiologica 205 324-340. (https://doi.org/10.1111/j.17481716.2012.02423.x)

Fainsod A, Deissler K, Yelin R, Marom K, Epstein M, Pillemer G, Steinbeisser H \& Blum M 1997 The dorsalizing and neural inducing 
gene follistatin is an antagonist of BMP-4. Mechanisms of Development 63 39-50. (https://doi.org/10.1016/S0925-4773(97)00673-4)

Fang L, Chang HM, Cheng JC, Yu Y, Leung PC \& Sun YP 2015 Growth differentiation factor-8 decreases StAR expression through ALK5mediated Smad3 and ERK1/2 signaling pathways in luteinized human granulosa cells. Endocrinology 156 4684-4694. (https://doi.org/10.1210/ en.2015-1461)

Findlay JK, Drummond AE, Dyson ML, Baillie AJ, Robertson DM \& Ethier JF 2002 Recruitment and development of the follicle; the roles of the transforming growth factor-beta superfamily. Molecular and Cellular Endocrinology 191 35-43. (https://doi.org/10.1016/S03037207(02)00053-9)

Furihata T, Kinugawa S, Fukushima A, Takada S, Homma T, Masaki Y, Abe T, Yokota T, Oba K, Okita K et al. 2016 Serum myostatin levels are independently associated with skeletal muscle wasting in patients with heart failure. International Journal of Cardiology 220 483-487. (https:// doi.org/10.1016/j.ijcard.2016.06.231)

Glister C, Tannetta DS, Groome NP \& Knight PG 2001 Interactions between follicle-stimulating hormone and growth factors in modulating secretion of steroids and inhibin-related peptides by nonluteinized bovine granulosa cells. Biology of Reproduction 65 1020-1028. (https:// doi.org/10.1095/biolreprod65.4.1020)

Glister C, Kemp CF \& Knight PG 2004 Bone morphogenetic protein (BMP) ligands and receptors in bovine ovarian follicle cells: actions of BMP$4,-6$ and -7 on granulosa cells and differential modulation of Smad-1 phosphorylation by follistatin. Reproduction 127 239-254. (https://doi. org/10.1530/rep.1.00090)

Glister C, Richards SL \& Knight PG 2005 Bone morphogenetic proteins (BMP) $-4,-6$, and -7 potently suppress basal and luteinizing hormoneinduced androgen production by bovine theca interna cells in primary culture: could ovarian hyperandrogenic dysfunction be caused by a defect in thecal BMP signaling? Endocrinology 146 1883-1892. (https:// doi.org/10.1210/en.2004-1303)

Glister C, Satchell L \& Knight PG 2010 Changes in expression of bone morphogenetic proteins (BMPs), their receptors and inhibin coreceptor betaglycan during bovine antral follicle development: inhibin can antagonize the suppressive effect of BMPs on thecal androgen production. Reproduction 140 699-712. (https://doi.org/10.1530/REP10-0216)

Glister C, Satchell L, Bathgate RA, Wade JD, Dai Y, Ivell R, AnandIvell R, Rodgers RJ \& Knight PG 2013 Functional link between bone morphogenetic proteins and insulin-like peptide 3 signaling in modulating ovarian androgen production. PNAS 110 E1426-E1435. (https://doi.org/10.1073/pnas.1222216110)

Glister C, Hatzirodos N, Hummitzsch K, Knight PG \& Rodgers RJ 2014 The global effect of follicle-stimulating hormone and tumour necrosis factor alpha on gene expression in cultured bovine ovarian granulosa cells. BMC Genomics 15 72. (https://doi.org/10.1186/1471-2164-15-72)

Gutierrez CG, Campbell BK \& Webb R 1997 Development of a longterm bovine granulosa cell culture system: induction and maintenance of estradiol production, response to follicle-stimulating hormone, and morphological characteristics. Biology of Reproduction 56 608-616. (https://doi.org/10.1095/biolreprod56.3.608)

Hasegawa T, Kamada Y, Hosoya T, Fujita S, Nishiyama Y, Iwata N, Hiramatsu Y \& Otsuka F 2017 A regulatory role of androgen in ovarian steroidogenesis by rat granulosa cells. Journal of Steroid Biochemistry and Molecular Biology 172 160-165. (https://doi.org/10.1016/j. jsbmb.2017.07.002)

Hatzirodos N, Hummitzsch K, Irving-Rodgers HF \& Rodgers RJ 2014a Transcriptome profiling of the theca interna in transition from small to large antral ovarian follicles. PLOS ONE 9 e97489. (https://doi. org/10.1371/journal.pone.0097489)

Hatzirodos N, Irving-Rodgers HF, Hummitzsch K, Harland ML, Morris SE \& Rodgers RJ 2014b Transcriptome profiling of granulosa cells of bovine ovarian follicles during growth from small to large antral sizes. BMC Genomics 15 24. (https://doi.org/10.1186/1471-2164-15-24)

Hedayati M, Nozhat Z \& Hannani M 2016 Can the serum level of myostatin be considered as an informative factor for cachexia prevention in patients with medullary thyroid cancer? Asian Pacific Journal of Cancer Prevention 17 119-123. (https://doi.org/10.7314/APJCP.2016.17.S3.119)

lemura S, Yamamoto TS, Takagi C, Uchiyama H, Natsume T, Shimasaki S, Sugino H \& Ueno N 1998 Direct binding of follistatin to a complex of bone-morphogenetic protein and its receptor inhibits ventral and epidermal cell fates in early Xenopus embryo. PNAS 95 9337-9342. (https://doi.org/10.1073/pnas.95.16.9337)

Islam MS, Catherino WH, Protic O, Janjusevic M, Gray PC, Giannubilo SR, Ciavattini A, Lamanna P, Tranquilli AL, Petraglia F et al. 2014 Role of activin-A and myostatin and their signaling pathway in human myometrial and leiomyoma cell function. Journal of Clinical Endocrinology and Metabolism 99 E775-E785. (https://doi.org/10.1210/jc.2013-2623)

Kambadur R, Sharma M, Smith TP \& Bass JJ 1997 Mutations in myostatin (GDF8) in double-muscled Belgian Blue and Piedmontese cattle. Genome Research 7 910-916. (https://doi.org/10.1101/gr.7.9.910)

Knight PG \& Glister C 2006 TGF-beta superfamily members and ovarian follicle development. Reproduction 132 191-206. (https://doi. org/10.1530/rep.1.01074)

Kurokawa M, Sato F, Aramaki S, Soh T, Yamauchi N \& Hattori MA 2009 Monitor of the myostatin autocrine action during differentiation of embryonic chicken myoblasts into myotubes: effect of IGF-I. Molecular and Cellular Biochemistry 331 193-199. (https://doi.org/10.1007/ s11010-009-0158-6)

Lee SJ \& McPherron AC 2001 Regulation of myostatin activity and muscle growth. PNAS 98 9306-9311. (https://doi.org/10.1073/ pnas.151270098)

Liang YC, Yeh JY \& Ou BR 2007 Effect of maternal myostatin antibody on offspring growth performance and body composition in mice. Journal of Experimental Biology 210 477-483. (https://doi.org/10.1242/jeb.02665)

Livak KJ \& Schmittgen TD 2001 Analysis of relative gene expression data using real-time quantitative PCR and the 2(-Delta Delta C(T)) Method. Methods 25 402-408. (https://doi.org/10.1006/meth.2001.1262)

Matzuk MM, Lu N, Vogel H, Sellheyer K, Roop DR \& Bradley A 1995 Multiple defects and perinatal death in mice deficient in follistatin. Nature 374 360-363. (https://doi.org/10.1038/374360a0)

McPherron AC \& Lee SJ 1997 Double muscling in cattle due to mutations in the myostatin gene. PNAS 94 12457-12461. (https://doi.org/10.1073/ pnas.94.23.12457)

McPherron AC, Lawler AM \& Lee SJ 1997 Regulation of skeletal muscle mass in mice by a new TGF-beta superfamily member. Nature 387 83-90. (https://doi.org/10.1038/387083a0)

Mendler L, Baka Z, Kovacs-Simon A \& Dux L 2007 Androgens negatively regulate myostatin expression in an androgen-dependent skeletal muscle. Biochemical and Biophysical Research Communications 361 237-242. (https://doi.org/10.1016/j.bbrc.2007.07.023)

Mosher DS, Quignon P, Bustamante CD, Sutter NB, Mellersh CS, Parker HG \& Ostrander EA 2007 A mutation in the myostatin gene increases muscle mass and enhances racing performance in heterozygote dogs. PLoS Genetics 3 e79. (https://doi.org/10.1371/journal.pgen.0030079)

Ono Y \& Sakamoto K 2017 Lipopolysaccharide inhibits myogenic differentiation of $\mathrm{C} 2 \mathrm{C} 12$ myoblasts through the Toll-like receptor 4-nuclear factor-kappaB signaling pathway and myoblast-derived tumor necrosis factor-alpha. PLOS ONE 12 e0182040. (https://doi.org/10.1371/ journal.pone.0182040)

Otto A \& Patel K 2010 Signalling and the control of skeletal muscle size. Experimental Cell Research 316 3059-3066. (https://doi.org/10.1016/j. yexcr.2010.04.009)

Palandra J, Quazi A, Fitz L, Rong H, Morris C \& Neubert H 2016 Quantitative measurements of GDF-8 using immunoaffinity LC-MS/MS. Proteomics: Clinical Applications 10 597-604. (https://doi.org/10.1002/ prca.201500112)

Peiris HN, Salomon C, Payton D, Ashman K, Vaswani K, Chan A, Rice GE \& Mitchell MD 2014 Myostatin is localized in extravillous trophoblast and up-regulates migration. Journal of Clinical Endocrinology and Metabolism 99 E2288-E2297. (https://doi.org/10.1210/jc.2014-2615)

Rebbapragada A, Benchabane H, Wrana JL, Celeste AJ \& Attisano L 2003 Myostatin signals through a transforming growth factor beta-like signaling pathway to block adipogenesis. Molecular and Cellular Biology 23 7230-7242. (https://doi.org/10.1128/MCB.23.20.7230-7242.2003)

Sahmi M, Nicola ES \& Price CA 2006 Hormonal regulation of cytochrome P450 aromatase mRNA stability in non-luteinizing bovine granulosa cells in vitro. Journal of Endocrinology 190 107-115. (https://doi. org/10.1677/joe.1.06827)

Samir M, Glister C, Mattar D, Laird M \& Knight PG 2017 Follicular expression of pro-inflammatory cytokines tumour necrosis factor-alpha (TNFalpha), interleukin 6 (IL6) and their receptors in cattle: TNFalpha, IL6 and macrophages suppress thecal androgen production in vitro. Reproduction 154 35-49. (https://doi.org/10.1530/REP-17-0053) 
Schiaffino S, Dyar KA, Ciciliot S, Blaauw B \& Sandri M 2013 Mechanisms regulating skeletal muscle growth and atrophy. FEBS Journal $\mathbf{2 8 0}$ 4294-4314. (https://doi.org/10.1111/febs.12253)

Schuelke M, Wagner KR, Stolz LE, Hubner C, Riebel T, Komen W, Braun T, Tobin JF \& Lee SJ 2004 Myostatin mutation associated with gross muscle hypertrophy in a child. New England Journal of Medicine 350 2682-2688. (https://doi.org/10.1056/NEJMoa040933)

Sheldon IM, Cronin JG, Healey GD, Gabler C, Heuwieser W, Streyl D, Bromfield JJ, Miyamoto A, Fergani C \& Dobson H 2014 Innate immunity and inflammation of the bovine female reproductive tract in health and disease. Reproduction 148 R41-R51. (https://doi.org/10.1530/REP-140163)

Shimasaki S, Moore RK, Otsuka F \& Erickson GF 2004 The bone morphogenetic protein system in mammalian reproduction. Endocrine Reviews 25 72-101. (https://doi.org/10.1210/er.2003-0007)

Silva JM \& Price CA 2002 Insulin and IGF-I are necessary for FSH-induced cytochrome P450 aromatase but not cytochrome P450 side-chain cleavage gene expression in oestrogenic bovine granulosa cells in vitro. Journal of Endocrinology 174 499-507. (https://doi.org/10.1677/ joe.0.1740499)

Skinner MK, Schmidt M, Savenkova MI, Sadler-Riggleman I \& Nilsson EE 2008 Regulation of granulosa and theca cell transcriptomes during ovarian antral follicle development. Molecular Reproduction and Development 75 1457-1472. (https://doi.org/10.1002/mrd.20883)

Valdes JA, Flores S, Fuentes EN, Osorio-Fuentealba C, Jaimovich E \& Molina A 2013 IGF-1 induces IP3 -dependent calcium signal involved in the regulation of myostatin gene expression mediated by NFAT during myoblast differentiation. Journal of Cellular Physiology 228 1452-1463. (https://doi.org/10.1002/jcp.24298)
Webb R, Nicholas B, Gong JG, Campbell BK, Gutierrez CG, Garverick HA \& Armstrong DG 2003 Mechanisms regulating follicular development and selection of the dominant follicle. Reproduction Supplement $\mathbf{6 1}$ 71-90.

Wu YG, Bennett J, Talla D \& Stocco C 2011 Testosterone, not 5alphadihydrotestosterone, stimulates $\mathrm{LRH}-1$ leading to $\mathrm{FSH}$-independent expression of Cyp19 and P450scc in granulosa cells. Molecular Endocrinology 25 656-668. (https://doi.org/10.1210/me.2010-0367)

Yang W, Zhang Y, Li Y, Wu Z \& Zhu D 2007 Myostatin induces cyclin D1 degradation to cause cell cycle arrest through a phosphatidylinositol 3-kinase/AKT/GSK-3 beta pathway and is antagonized by insulin-like growth factor 1. Journal of Biological Chemistry 282 3799-3808. (https:// doi.org/10.1074/jbc.M610185200)

Zhao Q, Yang ST, Wang JJ, Zhou J, Xing SS, Shen CC, Wang XX, Yue YX, Song J, Chen M et al. 2015 TNF alpha inhibits myogenic differentiation of $\mathrm{C} 2 \mathrm{C} 12$ cells through NF-kappaB activation and impairment of IGF-1 signaling pathway. Biochemical and Biophysical Research Communications 458 790-795. (https://doi.org/10.1016/j. bbrc.2015.02.026)

Received 1 March 2018

First decision 2 May 2018

Revised manuscript received 19 July 2018

Accepted 27 July 2018 